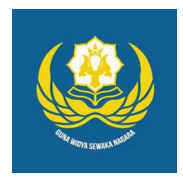

Jurnal Analogi Hukum

Journal Homepage: https://ejournal.warmadewa.ac.id/index.php/analogihukum

\title{
Peranan Bendesa dalam Penyelesaian Sengketa Tanah Waris di Desa Adat Buduk
}

\author{
I Gede Suka Widyantara*, I Ketut Sukadana dan Diah Gayatri Sudibya \\ Fakultas Hukum, Universitas Warmadewa, Denpasar, Bali-Indonesia \\ *sukawidyantara@gmail.com
}

\begin{abstract}
How To Cite:
Widyantara, I. G. S., Sukadana, I. K., \& ., Sudibya, D. G. (2020). Peranan Bendesa dalam Penyelesaian Sengketa Tanah Waris di Desa Adat Buduk. Analogi Hukum. 2(1). 32-36. Doi: http://dx.doi.org/10.22225/.2.1.1606.32-36

Abstract-In the inheritance system, people in Bali have a system of inheritance that originates from the male kinship system which causes the relationship to be emphasized more according to the husband's lineage. Generally, any inheritance disputes do not have to end in court, because disputes about inheritance involve adat law in their resolution. Moreover, if the inheritance land dispute is still a family dispute, then the settlement should also be settled amicably through the active role of the Bendesa as the Leader in Pakraman Village. The formulation of the problem in this study is: How is the regulation of inheritance in Pakraman Buduk Village?, What is the role of Bendesa in the settlement of inheritance land disputes in Pakraman Buduk Village? The problems discussed are examined from an empirical point of view. The results showed that the inheritance arrangement in Pakraman Buduk Village was in accordance with the contents of awig-awig Pakraman Buduk village contained in Palette 4 Pawos 75 to Pawos 78 which included inheritance, heirs, heir obligations, inheritance distribution, and loss of rights to be heir. The role of adat Bendesa in the settlement of inheritance land disputes in Desa Pakraman Buduk as a mediator.
\end{abstract}

Keywords: Inheritance, Bendesa, Dispute Resolution

\begin{abstract}
Abstrak-Dalam sistem kewarisan, masyarakat di Bali memiliki sistem kewarisan yang bersumber dari sistem kekerabatan laki-laki yang menyebabkan pertalian hubungan lebih dititikberatkan menurut garis keturunan suami. Umumnya pada setiap sengketa tanah waris tidak harus berakhir di pengadilan, karena sengketa tentang waris melibatkan hukum adat dalam penyelesaiannya. Apalagi kalau sengketa tanah waris tersebut masih merupakan sengketa yang bersifat kekeluargaan, maka penyelesaiannya pun seharusnya diselesaikan secara kekeluargaan melalui peranan aktif dari pihak Bendesa selaku Pemimpin di Desa Pakraman. Rumusan masalah dalam penelitian ini adalah Bagaimana pengaturan warisan di Desa Pakraman Buduk ?, Bagaimana peranan Bendesa dalam penyelesaian sengketa tanah waris di Desa Pakraman Buduk ?. Permasalahan yang dibahas dikaji berdasarkan sudut pandang empiris. Hasil penelitian menunjukkan, bahwa Pengaturan warisan di Desa Pakraman Buduk sesuai dengan isi awig-awig Desa Pakraman Buduk termuat dalam Palet 4 Pawos 75 sampai dengan Pawos 78 yang mencakup tentang harta warisan, ahli waris, kewajiban ahli waris, pembagian warisan, dan kehilangan hak untuk menjadi ahli waris. Peranan Bendesa adat dalam penyelesaian sengketa tanah waris di Desa Pakraman Buduk sebagai mediator.
\end{abstract}

Kata Kunci: Warisan, Bendesa, Penyelesaian sengketa

\section{Pendahuluan}

Tanah merupakan suatu hal penting bagi kehidupan manusia, karena manusia itu memerlukan sebidang tanah saat masih hidup sampai dengan meninggal dunia, mengingat pola kehidupan masyarakat dan perekonomian sebagian besar masyarakat masih bercocok tanam. Tanah mengandung makna yang sangat penting dalam kehidupan manusia. Pertama, ditinjau dari sisi ekonomi, tanah menjadi sarana produksi yang dapat mendatangkan kesejahteraan. Kedua, secara politis tanah dapat menentukan posisi seorang dalam pengambilan keputusan masyarakat. Ketiga, sebagai kapital budaya dan menentukan tinggi rendahnya status sosial pemiliknya. Keempat, tanah bermakna sakral karena 
setiap orang akan kembali kepada tanah pada akhir hayatnya (Arifin, 2015).

Permasalahan pewarisan bagi masyarakat Bali memiliki sistem pewarisan yang bersumber dari sistem kekerabatan laki-laki yang mempunyai ikatan/ hubungan lebih dititikberatkan menurut garis keturunan laki-laki. Maka laki-laki mempunyai kedudukan lebih utama daripada wanita. Laki-laki sebagai penerus garis bapaknya yang ditarik dari satu bapak asal, sedangkan wanita disiapkan untuk menjadi anak orang lain yang akan memperkuat keturunan orang lain. Maka dari itu jika dalam satu keluarga belum ada anak laki-laki dan tidak mempunyai keturunan laki-laki maka ia dapat dikatakan "putus keturunan". Sistem kekerabatan seperti ini di Bali lebih dikenal dengan Purusa (sistem keturunan laki-laki) (Hadikusuma, 1987).

Umumnya setiap sengketa tanah waris tidak selamanya harus melalui pengadilan, namun sengketa tentang tanah waris wajib mengikutsertakan hukum adat dalam penyelesaiannya. Dalam hal-hal tertentu setiap sengketa tanah waris yang muncul yang melibatkan warga desa idealnya dapat diselesaikan secara musyawarah di tingkat Desa Pakraman saja. Apalagi jika dalam sengketa tanah waris tersebut merupakan suatu sengketa yang memiliki sifat kekeluargaan, maka dalam penyelesaiannya pun diselesaikan dengan kekeluargaan dengan mediator pihak Bendesa selaku pemimpin di Desa Pakraman yang sudah menjadi tradisi dan tatakrama dalam pergaulan hidup secara turun-temurun dan terikat dengan Kahyangan Tiga yaitu Pura Desa, Pura Puseh, dan Pura Dalem.

Pengertian Desa Pakraman menurut Perda Provinsi Bali Nomor 3 tahun 2001 yang telah dirubah menjadi Peraturan Daerah Nomor 3 Tahun 2003 disebutkan, Desa Pakraman adalah kesatuan masyarakat hukum adat di Provinsi Bali yang mempunyai satu kesatuan tradisional dan tata krama pergaulan hidup masyarakat umat Hindu, secara turun temurun. Desa Pakraman merupakan desa otonom (sima swatantra) terdiri dari empat unsur yang merupakan syarat (Catur Bhuta Desa) diantaranya Parimandala (lingkungan wilayah desa); Karaman (warga desa); Datu (pengurus, pimpinan desa); dan Tuah (perlindungan dari Hyang Widhi).

Dalam tata Desa Pakraman, Awig-awig Desa Pakraman juga dikatakan roh agama Hindu yang merupakan penjabaran dari Tri Hita Karana, yaitu: parahyangan, palemahan dan pawongan.

Di Desa Pakraman Buduk sering ditemui kasus-kasus tentang tanah, selain dilatar belakangi oleh faktor ekonomi, juga dikarenakan masih lemahnya administrasi tanah. Kasus-kasus yang terjadi di Desa Pakraman Buduk tersebut sebagian besar telah di selesaikan melalui jalur Mediasi oleh Bendesa.

Berdasarkan pada pemaparan latar belakang maka dirumuskan permasalahan sebagai berikut: Bagaimana pengaturan warisan di Desa Pakraman Buduk ? dan Bagaimana peranan Bendesa dalam penyelesaian sengketa tanah waris di Desa Pakraman Buduk?

\section{Metode}

Tipe penelitian yang digunakan dalam penelitian ini adalah hukum empiris yaitu penelitian berdasarkan kenyataan-kenyataan di lapangan dan dikumpulkan dengan pengolahan data tertentu sedangkan pendekatannya adalah pendekatan sosiologis hukum yaitu suatu penelitian hukum yang mengkaji fakta-fakta hukum yang ada di masyarakat. Sosiologi hukum dapat diartikan sebagai ilmu pengetahuan yang umumnya menganalisis hukum secara empiris atau mempelajari hubungan timbalbalik antara hukum dengan gejala-gejala sosial yang ada dimasyarakat (Soekanto, 1989).

Penelitian ini diadakan di Desa Pakraman Buduk, Kecamatan Mengwi, Kabupaten Badung, karena masih banyak terdapat kasus-kasus tentang waris yang dapat diselesaikan secara kekeluargaan. Sumber data ada 2 (dua) yakni sumber data primer dan sumber data sekunder. Sumber data primer yaitu yaitu data yang diperoleh langsung di lokasi penelitian dengan mengadakan wawancara langsung dengan Bendesa, sedangkan data sekunder yang digunakan berupa Undang-undang No. 6 
Tahun 2014 tentang Desa, Perda Provinsi Bali Nomor 3 tahun 2001 yang telah dirubah menjadi Peraturan Daerah Provinsi Bali Nomor 3 Tahun 2003, buku-buku, literatur, dan Awig-awig Desa Pakraman Buduk.

Pengumpulan data yang diperlukan sangat beragam untuk mendapatkan data yang akurat, jelas dan terpercaya. Agar hasil yang dicapai dapat memuaskan serta sebagai bukti keberhasilan dalam mendapatkan data yang diperlukan di dalam penelitian yang dilakukan. Dalam pengumpulan data-data yang diperlukan menggunakan instrument data sebagai berikut: metode observasi, wawancara dan studi dokumen.

Setelah semua data terkumpul, kemudian data akan diolah sehingga data yang diperoleh dapat digunakan untuk menyelesaikan permasalahan yang ditemui dalam penelitian ini. Pengolahan data dalam penulisan skripsi ini dilakukan dengan menggunakan metode penelitian empiris yaitu analisis yang dilakukan dengan memahami dan menyusun data yang telah diperoleh secara langsung sehingga dapat digambaran mengenai masalah suatu keadaan yang diteliti. Analisis data dalam penelitian ini dilakukan scara kualitatif yaitu penelitian yang lebih memfokuskan sesuai dengan fakta yang terjadi dilapagan, kemudian dituangkan scara deskriptif (Arikunto, 2006).

\section{Hasil dan Pembahasan}

\section{Pengaturan Warisan Di Desa Pakraman Buduk}

Hukum waris adat dapat dikatakan sebagai hukum yang berisikan garis ketentuan mengenai suatu sistem dalam hukum waris, tentang pewarisan harta, pewaris dan waris serta alur warisan dari pemilik warisan dari pewaris kepada ahli waris. Hukum ini sebenarnya merupakan hukum lanjutan dari memindahkan harta kekayaan dari pewaris kepada keturunannya. Di dalam Hukum adat itu sendiri tidak mengenal cara-cara pembagian waris sesuai penghitungan dengan didasarkan pada pertimbangan, mengingat wujud benda dan kebutuhan waris yang bersangkutan.

Jadi sebenarnya hukum waris adat tidak semata-mata hanya mengatur tentang warisan dalam hubungannya dengan ahli waris tetapi lebih luas dari itu. Hilman Hadikusuma mengemukakan hukum waris adat adalah hukum adat yang memuat garisgaris ketentuan tentang sistem dan asas-asas hukum waris, tentang harta warisan, pewaris, dan waris serta cara bagaimana harta warisan itu dialihkan penguasaan dan pemilikannya dari pewaris kepada waris. Dalam hal ini terlihat adanya kaidah-kaidah yang mengatur proses penerusan harta, baik material maupun non material dari suatu generasi kepada keturunannya. Di dalam Hukum adat sendiri tidak mengenal caracara pembagian dengan penghitungan tetapi didasarkan atas pertimbangan, mengingat wujud benda dan kebutuhan waris yang bersangkutan.

Ada tiga sistem kewarisan yang dikenal dalam hukum adat diantaranya:

a. Sistem kewarisan individual.

b. Sistem kewarisan kolektif.

c. Sistem kewarisan mayorat

Menurut KUHPerdata, ahli waris terdiri dari empat kelompok, yaitu kelompok pertama terdiri dari suami atau istri yang hidup terlama ditambah anak atau anak-anak serta keturunan dari anak-anak tersebut. Kelompok kedua terdiri atas ayah dan ibu kandung (apabila keduanya masih hidup), ayah atau ibu (apabila salah satunya telah meninggal dunia) dan saudara atau saudari beserta keturunan dari saudara atau saudari tersebut. kelompok ketiga terdiri dari kakek dan nenek dari garis ibu. Kelompok terakhir (keempat) terdiri dari sanak keluarga pewaris yang lainnya.

Yang termasuk ahli waris dalam hukum adat Bali diantaranya anak lelaki dalam memiliki hubungan kebapakan (purusa). Akibat adanya ketentuan ini pada anak perempuan Hindu tidak dijadikan ahli waris. Sesuai hal tersebut berarti bahwa yang menjadi ahli waris adalah anak lelaki, sedangkan wanita dapat menjadi ahli waris apabila statusnya telah dirubah menjadi sentana rajeg. Selanjutnya keputusan lain 
menentukan bahwa "Hukum Adat Bali tidak melarang adanya hibah warisan (harta pusaka), seorang pewaris dapat menghibahkan warisannya kepada anak perempuannya yang disebut dengan tatatadan/bekal hidup/jiwadana.

Jadi laki-laki dengan perempuan mempunyai kedudukan yang tidak sama dalam pergaulan masyarakat Bali. Hal ini sesuai dengan Keputusan Pengadilan Tinggi Denpasar dan juga sudah merupakan Yurisprudensi (PT. Denpasar dan juga telah merupakan Yurisprudensi tanggal 22 Juli 1972 Nomor 105/ptd/1072/Pdt), yang menentukan bahwa seorang anak perempuan boleh mewaris apabila memperoleh status hukum laki-laki apabila dijadikan dikawinkan secara kaceburin (kawin dengan tetap tinggal di rumah asalnya yaitu pihak laki-laki yang meninggalkan rumah asalnya untuk kemudian ikut masuk dalam kekerabatan pihak perempuan) atau sentana rajeg.

$\begin{array}{ccc}\text { Sesuai } & \text { pendapat Bendesa } & \text { Desa } \\ \text { Pakraman } & \text { Buduk bahwa dalam }\end{array}$
penghibahan harta warisan dapat diberikan saat pewaris masih hidup. Apabila ahli waris itu melebihi dari satu orang, si pewaris pada umumnya sudah memberikan harta kekayaannya semasih hidup kepada para ahli waris bertujuan untuk menghindari adanya sengketa nantinya. Hal itu dapat dilakukan dengan cara pemberian yang sifatnya sementara ataupun tetap. Pemberian yang sifatnya sementara, misalnya adalah berupa pangupa jiwa, padum pamong atau padum raksa yang akan diperhitungkan kembali setelah pewaris meninggal atau di aben. Pengaturan Pewarisan di Desa Pakraman Buduk, Mengwi, Badung ada dalam awig-awignya yaitu pada palet 4 Pawos 75 sampai dengan Pawos 78.

Dengan demikian walaupun
meninggalnya pewaris dan upacara
pengabenan bukanlah syarat mutlak agar
harta warisan dapat dibagi tetapi
meninggalnya pewaris dan pengabenan
merupakan momen penting dalam proses
pewarisan dalam hukum adat Bali, karena
pada saat itu proses pewarisan menjadi
tuntas, harta warisan dapat dibagi secara
tetap dan proses "balik nama" terhadap

tanah dapat dilakukan. Pangupa jiwa adalah pemberian yang bersifat sementara. Ketika anak laki-laki yang pertama berumah tangga dan hidup mandiri (menehan), ia diberikan sepetak tanah untuk dikerjakan dan dihasil sendiri sebagai bekal kehidupan keluarganya, begitu seterusnya terjadi ketika anak laki-laki yang lain berumah tangga. Pemberian tersebut hanya bersifat sementara yang akan diperhitungkan kembali ketika pembagian warisan yang bersifat tetap telah dilakukan. Padum pamong artinya pembagian harta warisan yang bersifat sementara sampai diadakan pembagian tetap.

\section{Peranan Bendesa Dalam Penyelesaian Sengketa Tanah Waris Di Desa Pakraman Buduk}

Konflik terjadi karena masing-masing pihak bersaing untuk mencapai tujuannya masing-masing dan dalam persaingan itu tentunya akan ada upaya untuk mengalahkan pihak lain dan dengan demikian salah satu pihak meraih kemenangan. Di dalam persaingan ini mungkin pula muncul persaingan yang tidak sehat yang menimbulkan kerugian pada pihak lain yang akhirnya melahirkan sengketa (Sembiring, 2011).

Sengketa semacam inilah yang memerlukan penyelesaian yang memadai sehingga situasi dalam kehidupan masyarakat adat dapat berada dalam suasana kondusif, aman dan damai. Selesai tidaknya sengketa yang terjadi akan sangat tergantung kepada model atau pola penyelesaian sengketa yang digunakan dan didukung oleh kemampuan dari personal yang terlibat dalam penyelesaian sengketa tersebut. Pengaturan tentang ketentuan penyelesaian sengketa dalam awig-awig Desa Pakraman Buduk memang tidak ada, tetapi pihak Bendesa mengharapkan krama desanya atau warganya dalam penyelesaian sengketa tentang waris dapat diselesaikan melalui musyawarah dengan berpedoman pada awigawig yang ada.

Sesuai pada data yang diperoleh pada tempat penelitian tujuan dilakukannya mediasi oleh Bendesa Desa Pakraman Buduk dalam menyelesaikan sengketa tanah yang terjadi di Desa Pakraman Buduk yaitu dijelaskan dalam Pawos 16 Awig-awig Desa Pakraman Buduk yang berbunyi :

- Swadharmaning prajuru desa adat luire: 
- ha. Ngenterang pelaksanaan sadaging awig-awig, pararem miwah pasuara desa.

- na. Nuntun tur ngenterang krama rauhing warga desane ngulati anut petitis.

- ca. Nuntun saha nyaksinin tata cara miwah sangaskaraning kahuripan mabuat sane ngilitang sulur pakulawargan.

- ra. Maka duta utawi utusan matemuang bawos ring sapsira ugi.

- ka. Mawosin kalih nirwakang pamutus marep ring wicaran warga desane.

Prade prajuru nenten manut ring swadharma utawi nilar sesana, kengin kawusang tur patut keni pamidanda manut pararem.

\section{Artinya :}

- Tugas prajuru desa adat dalam hal ini Bendesa adat adalah :

- sebagai pelaksana pemerintahan melaksanakan apapun isi awig-awig dan keputusan rapat desa;

- Menuntun dan mengarahkan agar krama bisa berjalan di dalam koridor;

- Tugas seorang Bendesa adat boleh dijadikan utusan (mediator) mempertemukan krama adat yang bersengketa;

- Bendesa boleh membahas (menjadi mediator) termasuk mengeluarkan keputusan.

Jika prajuru desa berlaku tidak benar atau keluar dari koridor, patut ditegur dan juga dikenakan sanksi menurut rapat desa.

Para pihak yang ikut serta dan hadir dalam mediasi yang dilakukan oleh Desa Pakraman Buduk yaitu: Tim Kerta Desa; Prajuru Desa Pakraman; Para pihak yang bersengketa; Saksi -saksi. Pada bagian akhir isi putusan yang dikeluarkan oleh Bendesa Desa Pakraman Buduk tersebut berisi ketentuan: "Bilamana bagi para pihak yang bersengketa tidak puas akan Putusan Desa Pakraman ini dapat dilanjutkan melalui pengadilan dan dalam pelaksanaan mediasi dihadiri oleh perbekel sebagai saksi dari unsur pemerintah (kedinasan)"

\section{Simpulan}

Sesuai pemaparan pada latar belakang dan pada pembahasan dari permasalahan yang diajukan maka dapat disimpulkan bahwa : 1) Pengaturan warisan di Desa Pakraman Buduk sesuai dengan isi awig-awig Desa Pakraman Buduk ada dalam yaitu pada Palet 4 Pawos 75 sampai dengan Pawos 78 yang mencakup tentang harta warisan, ahli waris, kewajiban ahli waris, pembagian warisan, dan kehilangan hak untuk menjadi ahli waris. 2) Peranan Bendesa adat dalam penyelesaian sengketa tanah waris di Desa Pakraman Buduk sebagai mediator. Mengingat Bendesa merupakan jabatan struktural adat tertinggi di suatu desa. Peran Bendesa Pakraman Buduk dalam menyelesaikan sengketa waris di Desa Pakraman Buduk ini yaitu dengan cara mengadakan mediasi agar sengketa yang terjadi dapat diawali dengan membentuk kerta desa, selanjutnya diselesaikan secara kekeluargaan dan jika penyelesaian secara musyawarah tidak mencapai kata sepakat maka akan dilanjutkan ke tahapan hukum positif (ke pengadilan).

\section{Daftar Pustaka}

Arifin, A. (2015). Upaya Penyelesaian Sengketa Tanah Hak Milik Berbasis Adat Istiadat. Retrieved from http:// juslansh.blogspot.com/2012/11/ proposal-penelitian-tesis-juslan.html

Arikunto, S. (2006). Prosedur Penelitian Suatu Pendekatan Praktik. Jakarta: Rineka Cipta.

Hadikusuma, H. (1987). Hukum Kekerabatan Adat. Jakarta: Fajar Agung.

Sembiring, J. J. (2011). Cara Menyelesaikan Sengketa di Luar Pengadilan (Negosiasi, Mediasi, Konsiliasi, \& Arbitrase) (Cet. Pertama). Jakarta: Visimedia.

Soekanto, S. (1989). Mengenal Sosiologi Hukum. Bandung: Citra Aditya Bakti.

Awig-awig Desa Pakraman Buduk.

Perda Provinsi Bali Nomor 3 tahun 2001 yang telah dirubah menjadi Peraturan Daerah Nomor 3 Tahun 2003 tentang Desa Pakraman.

Undang-undang No. 6 Tahun 2014 tentang Desa. 